\title{
STRUCTURAL AND LEGAL ANALYSIS OF SCIENTIFIC ACTIVITY REGULATION IN DEVELOPED COUNTRIES
}

\author{
Yevgeny Leheza' \\ University of Customs and Finance, Ukraine \\ Maryna Savielieva ${ }^{2}$ \\ Dnipropetrovsk State University of Internal Affairs, Ukraine \\ Olena Dzhafarova ${ }^{3}$ \\ Kharkiv National University of Internal Affairs, Ukraine
}

\begin{abstract}
Experience of developed countries makes the case that it is possible to achieve a high level of competitiveness in the globalized market solely by using achievements of scientific-and-technological advance. National policy and effectiveness of means of scientific sector support used in the country are essential to it. The purpose of the article is an effort to perform the structural analysis of support, regulation, and financing of scientific activity in world's major economies, having determined central institutes of financial means command for the investment into innovative and scientific activity in the countries. To perform a functional analysis of the funded status of Ukrainian scientific and technological and educational activity from the standpoint of its public regulation. Based on the studied funding model of scientific activity in developed countries, to propose the model of optimization of scientific activity financing that will become the innovative activator of support and development of Ukrainian science. Analysing public policy of developed countries related to the support of scientific, educational, and innovative activity according to the degree of state regulation, it is possible to identify two poles. The first pole can be notionally named as English-American model where the state does very little to interfere with the activity of scientific and innovative sector. It is characterized by the fullest autonomy of entrepreneurship in the innovative and scientific and educational sphere. With the use of such model, it is assumed that market mechanisms facilitate acceleration of scientific and innovative processes of country development by them. The second pole, a Franco-Japanese model of public regulation, is characterized by the substantial impact of the state on scientific and educational processes, in particular, by non-market financing methods. With the use of this model, the governments determine priority guidelines of innovative and technological development supported by the government substantially; such countries to some extent include: France, Sweden, and Japan. Most of the developed European countries (Germany, Poland, Italy) and Canada are found in between specified poles of scientific and innovative policy while developing a national business environment and using direct state support of innovative activity. The increase in expenses of the private sector for research and development activities appears in all countries. Public authorities support scientific studies, innovative activity and development of small and medium-sized businesses in a scientific and technological sphere; they cooperate actively during the development and implementation of national programs. Moreover, other concerned parties - industrial companies, representatives of the academic community, non-governmental non-profit organizations - are involved more actively in the decision-making process. Max Planck Society in Germany can become the experimental model of regulation and financing of scientific, educational, and innovative activity of institutions. Implementation of a new economic model in Ukraine is possible upon the condition of creation and adjustment of the functioning of two closed and
\end{abstract}

\footnotetext{
Corresponding author:

${ }^{1}$ Department of Administrative and Customs Law, Faculty of Law, University of Customs and Finance.

E-mail: legeza@email.ua

${ }^{2}$ Department of Civil Law and the Process of the Faculty of Specialist Training for the Criminal Police Departments,

Dnipropetrovsk State University of Internal Affairs.

E-mail: Savielieva@i.ua

${ }^{3}$ Department of Police Administrative Activities, Kharkiv National University of Internal Affairs.

E-mail: olenadzhafarova@gmail.com
} 
related engineering processes: innovative and productive: education-science-production-market; investment. The following may be classified as top priorities of development of scientific and technological activity in Ukraine: prevention of arrival of earlier and inefficient technologies; facilitation of application of state-of-the-art highly efficient technologies, development of scientific potential and human resourcing; arrangement of conditions for extension and expansion in the number of innovative structures (technology parks, technopolis, business incubators, innovation centres, innovative exchange markets).

Key words: regulation of scientific activity, funding model, English-American model, Franco-Japanese model, Canadian model, R\&D of Ukraine, science financing, Max Planck Society.

JEL Classification: $\mathrm{H} 52, \mathrm{H} 60, \mathrm{I20}, \mathrm{I28}, \mathrm{K} 10$

\section{Introduction}

Current stage of world economy's development is characterized by accelerated paces of scientific-andtechnological advance and increasing intellectualization of prime production factors. Under these circumstances, the development of productive forces is carried out upon the condition of close cooperation of science and up-to-date technologies; creation and implementation of innovations is prime success factor of state in presentday conditions. Experience of developed countries makes the case that it is possible to achieve a high level of competitiveness in the globalized market solely by using achievements of scientific-and-technological advance. National policy and effectiveness of means of scientific sector support used in the country are essential to it. The efficiency of implementation of innovative changes in Ukraine depends directly on an understanding of market laws, the highest consistency of economic mechanisms of effective use of innovative capacity.

Scientific sphere reform provides a range of structural transformations of the system of science organization and functioning in Ukraine relating to academic and branch scientific institutions and higher education establishments. The state can influence on social and economic and other processes in the society, to regulate social and economic relations by means of scientific activity management.

\section{Recent research and publications analysis}

Problems of public regulation of scientific and scientific and technological activity and mechanisms of science financing were reviewed in papers of scientists and experts, in particular: E. Brooking, M.P. Butko, O.B. Butnik-Siverskyi, V.M. Heiets, J. Galbraith, D. Duffy, A.O. Diehtiar, L. Edvinsson, A.H. Zharinova, S.M. Illiashenko, V.L. Inozemtsev, B.B. Leoniev, L. Malone, L.H. Melnyk, V.P. Semynozhenko, T. Stuart, A. Toffler, A.A. Chukhno, S.M. Shkarlet. Scientists made a significant contribution to the study and analysis of theoretical and practical aspects of scientific and scientific and technological activity. The attention in published papers is given to developments of the concept of scientific and technological policy, forms and methods of science financing, state of the art and main trends in the future; certain papers cover the experience of foreign countries in the formation of the funding model.

\section{Identification of unresolved issues being the part of the general problem}

However, the issue of international scientific and scientific and technological cooperation is at the level of discussions and search for ways of its activation. Opportunities for use of existing foreign models are considered in a generalized sense, without regard to modern trends of development, global and Ukrainian scientific potential.

Moreover, the financing of scientific and technological and educational activity is considered from the standpoint of general obtained results, i.e. science is perceived as the business activity, without regard to problems and opportunities of development of that particular potential of the innovative integrator of country development.

\section{Structural analysis of scientific activity funding models in developed countries}

Analysing public policy of developed countries related to support of scientific, educational and innovative activity according to the degree of state regulation, it is possible to identify two poles.

One pole includes the USA and England where the state does very little to interfere with the economy, in particular, the scientific and innovative activity; the other pole includes France and Japan where the scientific and innovative processes are actively supported by the state.

The first pole can be notionally named as EnglishAmerican model. It is characterized by the fullest autonomy of entrepreneurship in the innovative and scientific and educational sphere. With the use of such a model, it is assumed that market mechanisms facilitate acceleration of scientific and innovative processes of country development by them. The main emphasis is placed on the creation of favourable conditions for the conduct of business in general, thus providing for the creation of satisfactory conditions for implementation of innovative products in the branch of national economy. 
The second pole, a Franco-Japanese model of public regulation, is characterized by the substantial impact of the state on scientific and educational processes, in particular, by non-market financing methods, by means of direct government grants and subsidies of enterprises carrying out the innovative activity. With the use of this model, the governments determine priority guidelines of innovative and technological development supported by the government substantially; such countries to some extent include: France, Sweden, and Japan.

Most of the developed European countries (Germany, Poland, Italy) and Canada are found in between specified poles of scientific and innovative policy while developing a national business environment and using direct state support of innovative activity.

The increase in expenses of the private sector for research and development activities appears in all countries. Public authorities support scientific studies, innovative activity and development of small and medium-sized businesses in a scientific and technological sphere; they cooperate actively during development and implementation of national programs. Moreover, other concerned parties - industrial companies, representatives of the academic community, non-governmental non-profit organizations - are involved more actively in the decision-making process.

The extent of management centralization may be different, but there is always interdepartmental regulation organized in a certain way (continuous or periodic arising by reason of the necessity of solution of specific problems).

\section{Countries with the decentralized type of scientific activity regulation}

Great Britain, the USA, and Germany belong to European countries that have strong scientific potential and where the management of the scientific industry is considered to be the most efficient.

Scientific and technological potential of Great Britain was developed on the basis of conducting research and development in three sectors: public sector, the institutions of which pursue the researches of the fundamental and applied nature; higher education sector providing fundamental researches; scientific and technological units of private companies where the applied researches and developments, implementation of new technologies and its commercial realization are concentrated. Distribution by sectors of research and development conducting is approximately the following: government laboratories - 15.3\%; higher school 13.75; private companies, research public corporations and laboratories, investigatory associations 84.35; other organizations - 3.75 (Danylova, 2014).

Government funding is focused on science support, updating of technical and scientific basis, maintenance of the position of Great Britain as one of the global scientific leaders, maximization of application of research results in the sector of the economy, and promotion of innovations in social and other spheres.

The government supports small-scale profitable projects, provides the technical basis for researches and finances engagement of leading scientists and researchers into the scientific sector of Great Britain. Cooperation between universities is of prime importance so as the critical amount of scientific researches could appear that will become a basis for important scientific achievements. Therefore, work in Great Britain is offered to leading scientists from other countries of the world, in particular, Eastern Europe.

Scientific and technological potential characterizes only potential opportunities of achievement of effect from the scientific and technological activity. The level of a country's industrial development depends significantly on social and economic content, objects and forms of scientific and technological policy. Public scientific and technological policy is based particularly on the priorities of general economic policy and includes the following courses: the creation of institutional basis of R\&D regulation; direct financing of $R \& D$ and education; provision of incentives for $\mathrm{R} \& \mathrm{D}$ with the use of tax and depreciation policy; development of scientific and technological infrastructure.

Generally scientific and technological policy of Great Britain consists of two basic elements: financing and management, where management acts as synthesizing element of all components of research and manufacturing complex "research - developments production - consumption"; it forms connection between scientific studies and applied developments with economy in whole (Danylova, 2014).

Decentralized type is the most evident in the USA where the majority of ministries and agencies are involved in the processes of regulation and financing of scientific and innovation policy. However, the extent of involvement of the executive authorities is unequal: more than $90 \%$ of the federal budget for R\&D is allocated through six ministries and agencies: Department of Defence, Department of Health, Department of Energy, Department of Agriculture, National Science Foundation, National Aerospace Agency (Danylova, 2014; Bolohib, 2005).

The main regulatory authority of scientific sphere of the USA is federal legislation and "federal programs" in the branch of scientific-and-technological advance. They form the special unit of public and legal regulation intended for development and scientific and technological capacity-building and implementation of strategic and tactical tasks of public scientific and technological and military-technical policy. They are updated from time to time according to state needs or the requirements of the scientific and technological policy of the federal agencies. These laws - programs usually carry out the national-level and interdepartmental 
coordination of scientific and technological, industrial and military-technical policy, its relation to the domestic or foreign policy of the USA.

A key aspect of the American education system is its full integratedness into practical issues of the corporate sector. The education system and corporate sector of the USA are integrated into entire institutional formation dealing with general issues. Universities always have the lead in this system, warning corporations of potential problems with their studies, and train specialists able to solve these problems. It is exactly that particular approach to the arrangement of scientific and educational activity that makes the American system the most powerful and efficient in the world (Lutsenko, 2015).

Improvement of procedures and mechanisms of the assessment of the efficiency of implementation of measures of science policy becomes the important course of development of public regulation of scientific sphere in the USA. High priority is assigned to such forms of assessment as international comparisons, pilot studies, and expert review. The exercise of consultations with interested participants of the innovative system is integrated into the mechanism of assessment for the purpose of consensus-building on the issues of science policy. Assessment can be carried out prior to the start of measures implementation, during the process, as well as upon completion of the governmental initiative. Assessment of measures of science policy in the USA is implemented for the purpose of determination of the level of achievement of the desired objective, as well as for the provision of strict control over budget expenditures (Lutsenko, 2015). In other countries where the assessment is carried out on a regular basis, it focuses mainly on substantiation of budget expenditures for research, development, and formation of a general assessment of the efficiency of the whole system of scientific management.

In such a case, the objects of assessment may vary, for example, programs, certain technologies, management arrangement, international aspects of the scientific activity, relations between scientific institutions and companies, operational conditions of scientific institutions etc.

Series of modernization of the sphere of researches and developments are implemented in the developed countries. Countries of European Community trying to eliminate the available technological inferiority in comparison with the USA work the most actively towards it.

\section{Countries with the centralized type of scientific activity regulation}

France, Sweden, and Japan may serve as the examples of the centralized model of scientific and innovation activity regulation and financing.

French National Centre for Scientific Research (Centre National de la Recherche Scientifique - CNRS) is a leading public institution of the fundamental studies.
CNRS is included into the ministry of scientific studies and technologies, has its own staff of scientists and self-financing; it also has 18 representative offices within the territory of the country and more than ten representative offices abroad.

CNRS has its own research laboratories and project groups, two institutes - National Institute for Earth Sciences and Astronomy (Institut national des sciences de l'Univers) and the National Institute of Nuclear and Particle Physics (Institut national de physique nucléaire et de physique des particules). CNRS has a certain priority while allocating public scientific subsidies; $25 \%$ from all funds allocated for non-military research needs are accounted for by it (Yadranska, 2007).

So, the system of public administration of science is implemented in France. However, rather a low percent of administrative expenses should be noted. The second special aspect of the fundamental science functioning in France consists of the fact that the laboratories rather than the institute (CNRS includes only two institutes) are the basic structural units. In addition, the absolute majority of laboratories have dual subordination (mostly, in cooperation with universities). However, the single policy established by CNRS is implemented in all laboratories; uniform rules of creation, control and dissolution, coordination of the activity are in force.

Leading scientificinstitution of Italy is CNR(Consiglio Nazionale delle Ricerche) - National Research Council. It is the public organisation the mission of which consists in carrying out, dissemination, transfer, and improvement of exploratory activity in basic sectors of knowledge growth and application of this knowledge for the purpose of scientific, technological, economic, and social development of the country.

The primary source of CNR financing is a state, but the market also contributes its share: to the tune of $30 \%$ of CNR profits are gained from the works on external orders and in agreement with the companies, contracts with the European Union and international organizations. The share of CNR administrative expenses - $9 \%$ - is the highest among the studied countries.

Sweden is the next country with centralized management having substantial scientific and technological potential. Sweden is eager to take a position among leading countries in the branch of Research and Development where research scientific works are characterized by width and specialization.

Swedish scientific and research developments receive funding mainly (for 75\%) from the business sector. The state is the primary source of scientific work financing in universities and other higher educational institutions. Funds for these purposes are allocated in the form of direct government subsidies and grants from various scientific councils and other government agencies and establishments (Yadranska, 2007, Danylova, 2014).

Four public institutions deal directly with the financing of scientific studies and developments: 
1. Swedish Research Council (Vetenskapsrådet) financed the research (ca. 4 bln krona) in the branch of natural sciences, technology, medicine, human and social sciences in 2016.

2. Swedish Research Council for Environment, Agricultural Sciences and Spatial Planning (Formas) allocated ca. 850 bln krona in 2015.

3. Swedish Council for Working Life and Social Research (FAS) allocated for the study of problems of the labour market, job arrangement, occupational diseases, medicare, well-being, social service ca. 400 bln krona in 2015-2016.

4. Sweden's innovation agency (Vinnova) financed the research in the branch of technologies, transport, communications and labour relations in 2016. Approximate amount of 1.5 bln krona was allocated (Martynyuk, 2014).

There are also non-profit foundations in the civilian sector being the important supplement to government financing of science. However, they take the second place.

Creation of a centralized model of regulation and financing of scientific activity in Japan was launched in 1949 when Japan Science Council was established as a special agency headed by the prime minister of the country for the purpose of science promotion in the government, industry, and in social life.

Council obligations include approval of decisions on the important scientific problems and ensuring of the efficient exchange of knowledge between the scientists for the purpose of the provision of scientific studies productivization. 210 members of Science Council are elected from ca. 760 scientists throughout the country.

Japanese Society for the Promotion of Science (JSPS) is an independent administrative institute established for the purpose of facilitation of promotion of science in all spheres - natural, social, and humanitarian. JSPS is essential to the management of a wide range of Japanese academic and scientific programs. JSPS was established in 1932 as the non-profit organization with the use of contributions made by the emperor. Since October 1, 2003, JSPS entered into a new stage of its development due to the fact that it was transformed into an independent administrative institute for the purpose of optimization of the management efficiency, improvement of the quality of services proposes by JSPS to the universities and research institutes (Bolohib, 2005).

JSPS activity is supported mainly by annual subsidies from the government of Japan. JSPS established the Research centre of scientific paradigms in 2003 in order to carry out consultations on the important issues of JSPS program, in particular, related to allocation of grants, estimation criteria, register of candidates list, as well as recommendations on the new formats and grant systems. Despite the fact that the universities receive much funding from the industry, the grants remain the primary source of the academic activity funding, in particular, the projects initiated by the researchers themselves.

\section{Countries with mixed type of scientific activity regulation}

The continental model - the combined system of the arrangement, management, and financing of the fundamental studies joining state and private sector financing - is characterized for leading countries of European Community.

The share of state (budgetary) financing of researches and developments is the biggest; the system is also determined by the availability of big scientific institutes involved into management and financing of the fundamental science. In addition, it is recognized at the domestic level that the continental model is excessively bureaucratized and does not comply with present-day challenges and needs, so it needs reformation, and it is determined by each country according to its own scenario.

The following hazards of European scientific and educational economy sector are identified: the ageing of scientists and researchers staff; complicatedness of the administrative system; inflexibility of scientific studies system - regional misbalance; concentration of scientific potential in metropolitan areas; poor attraction of academic career; low level of science internationalization. Latest researches confirm the efficiency of the increase in sources of funding for scientific studies and developments from the private sector.

Germany has its special federal system of scientific studies arrangement, with the assignment of responsibilities between federal and local government. It is divided into higher education sector and scientific studies sector. State financing of various aspects of researches is arranged in three ways: from federal budget; from local budgets (for example, higher educational institution, Research and Development Establishment); in cooperation from federal and local budgets.

State-financed nationally significant research establishments are co-financed from federal and local budgets; they are combined into four big networks. Financial support for the pursuance of scientific studies and developments is obtained from three sources.

The first source is state budget covering one-third of German expenditures for science. The second source is private companies. A few percent in the financing of research scientific work and experimental and design work is accounted for by funds and private non-profit organizations. During the past decade, the extended assessment of higher education institutions and scientific and research sector was carried out for the purpose of the most efficient reformation.

Canada also formed its unique model of scientific activity financing over the course of the past century (Pysmennyy, Pysmennyy, 2013).

Canada National Research Council (NRC) is the main governmental organization on scientific and technological researches established in 1916. Council consists of more than 20 institutes and national programs 
covering the wide range of academic disciplines. Institutes and programs are arranged into three big groups: physical and technical; life and information technologies sciences; technologies and commercial developments.

National Research Council is the governmental agency of Canada reporting with the aid of the Minister of Industry and supervised by 22 elected representatives of the scientific community.

Goals and tasks of NRC are the following (Kuzhelyev, 2015):

- pursuance and support of scientific studies and commercial developments essential to Canada;

- arrangement, management, and maintenance of national scholarly library;

- publishing and sale (or other dissemination) of scientific and technical information;

- development of assessment criteria;

- development of standards and certification of Canadian industry;

- management of astronomical observatories established or financed by the government of Canada;

- management of scientific research including grants and contributions for the purpose of support of NRC international activity;

- provision of research and industrial community with state-of-the-art scientific and technological support.

\section{Results and discussion}

According to Art. 48 of the Law of Ukraine "On Science and Scientific and Technological Activity" dd. November 26, 2015, No. 848-VIII, the budgetary financing of science and (or) scientific and technical activity using the funds of common fund of state budget is allocated for the provision of: 1) primary activity of state scientific institutions funded through the budget and scientific studies of universities, academies, institutes; 2) implementation of certain scientific and scientific and technical programs, projects and assignment of grants (Pro vnutrishnye ta zovnishnye stanovyshche Ukrayiny v 2016 rotsi (2017).

The supplement No. 3 "Allocation of costs of State budget of Ukraine for 2016" to the Law of Ukraine "On State Budget for 2016" provides the volume of costs for the financing of the Office of the Ministry of Education and Science of Ukraine in the amount of $14.581 \mathrm{mln}$ UAH; the amount equal to $85.43 \mathrm{bln} \mathrm{UAH}$ was allocated in 2017; the amount equal to $95.47 \mathrm{bln}$ UAH was allocated in 2018. The amount of nationallevel expenses and crediting of the educational system was equal to $63.69 \mathrm{bln}$ UAH from this sum.

In 2018 , the amount equal to 23.29 bln UAH was allocated for training of personnel at higher educational institutions and provision of operation of their practice basis; the amount equal to 3.16 bln UAH was allocated for payment of academic scholarships to students; the amount equal to $1.35 \mathrm{bln}$ UAH was allocated for training of personnel at Taras Shevchenko National University of Kyiv (Pro derzhavnyy byudzhet na 2018).

Methodological and material support of the activity of educational institutions in 2018 will be financed in the amount of $990.6 \mathrm{mln} \mathrm{UAH}$; the amount of financing of researches, science and scientific and technical developments is equal to $929.4 \mathrm{mln}$ UAH. In addition, the amount of $347.7 \mathrm{mln} \mathrm{UAH}$ will be allocated for the purpose of fulfilment of Ukrainian obligations in framework EU research and innovation program "Horizon 2020"; the amount of $233 \mathrm{mln}$ UAH will be allocated for the external assessment and education quality monitoring by the Ukrainian centre of education quality assessment; the amount of $208.9 \mathrm{mln} \mathrm{UAH}$ will be allocated for training of regular labour forces at the vocational-technical schools. The Law "On State Budget for 2018” came into effect on January 01, 2018. Revenues are provided in the amount of $917.88 \mathrm{bln} \mathrm{UAH}$; expenses are provided in the amount of $991.7 \mathrm{bln}$ UAH.

The economic basis of the activity of the National Academy of Sciences of Ukraine is formed by basic funds, current assets, and intangible assets, including the expenditures from the State Budget of Ukraine, allocated for the provision of statutory activity of the National Academy of Sciences of Ukraine. Numerousness of personnel engaged in the scientific sphere is considered to be the important resource factor. A number of employees engaged in $R \& D$ were equal to 97.9 thousand of employees in 2016 (with due regard to part-time employees and persons working according to independent contractor agreements) where $65.1 \%$ are researchers, $10.2 \%$ are technicians, $24.7 \%$ are support staff. The proportion of Dr.Sc. and Ph.D. (candidates of sciences) among R\&D performers was equal to $27.9 \%$; among researchers, this number was equal to $42.6 \%$. The share of women in the total quantity of researchers was equal to $45.0 \%$ where $6.6 \%$ had the academic degree of Dr.Sc. and 33.0\% had the academic degree of Ph.D. (candidate of sciences) (Shevchenko, Shadura, 2017).

Declining number of scientists (R\&D performers) remains the serious problem. It is caused by the low prestige of scientific work and social protection of scientists resulting in an outflow of young, talented scientists into other spheres of economic activity or their emigration abroad. Scientific and scientific and technical work reflects the total economic status of the state in general.

Ukraine is represented in the global market mainly by the products of the defence-industrial sector and airplane industry. The analysis of statistical data on the sources of funding of scientific and scientific and technical activity shows that science works mainly using budget and customers' funds. The proportion of $R \& D$ performers in Ukraine (researchers, technicians and support staff) in 2016 in the total quality of working population was equal to $0.60 \%$ where the proportion 
Vol. 4, No. 3, 2018

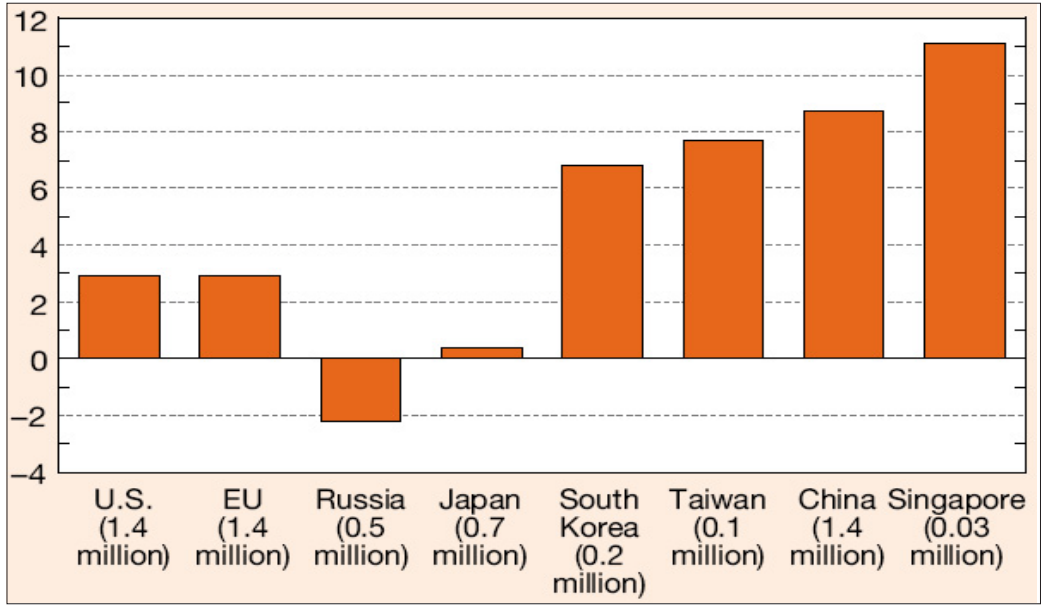

Fig. 1. Number of the population in developed countries engaged in scientific research (as of 2014)

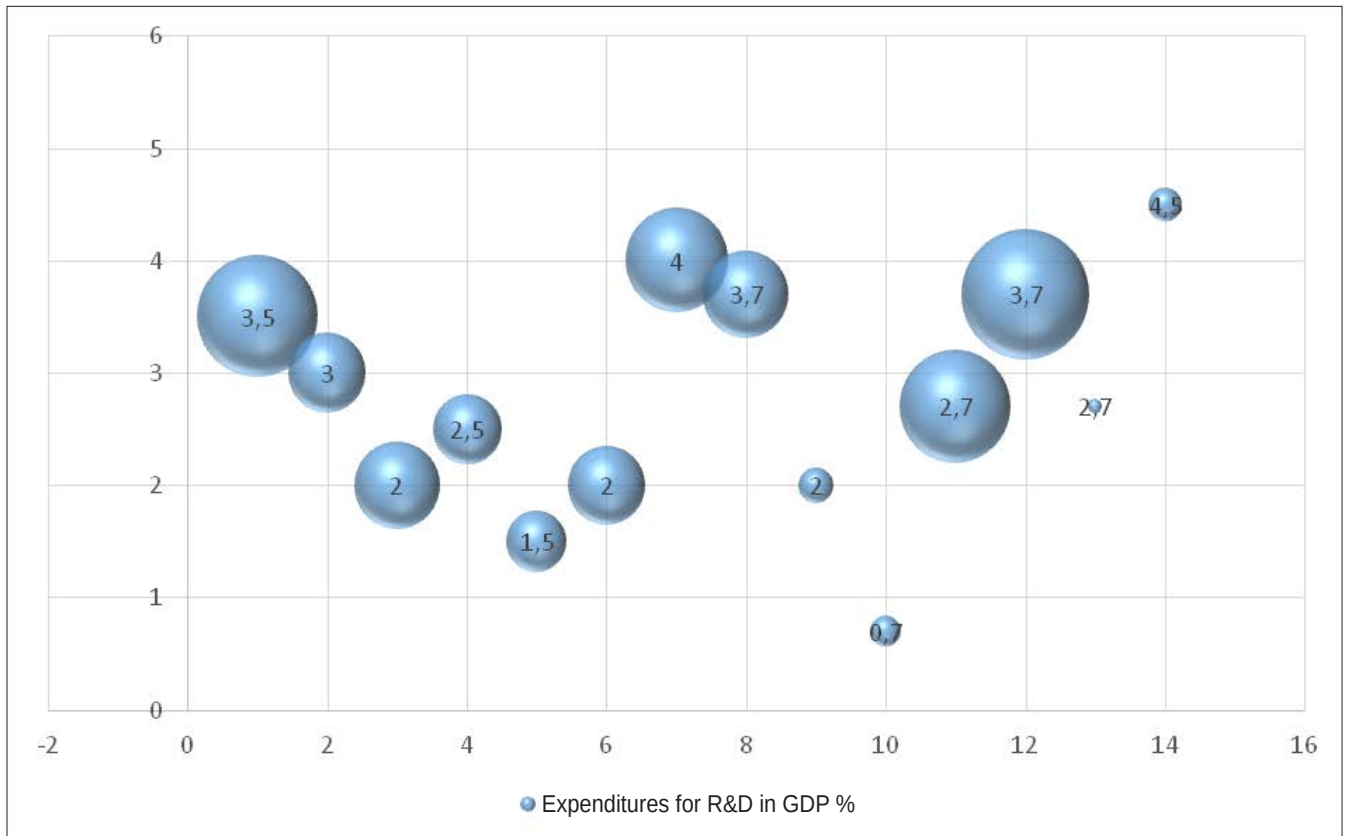

Fig. 2. Distribution of countries according to the amount of R\&D financing in \% from GDP in terms of 1 million of citizens in 2016

of researchers was equal to $0.39 \%$. According to data of Eurostat, in 2014 these proportions were the highest in Denmark (3.07\% and 2.09\%), in Finland (2.95\% and $2.12 \%)$ and in Norway $(2.73 \% / 1.90 \%)$. However, they were the lowest in Romania $(0.48 \% / 0.31 \%)$, in Cyprus
$(0.69 \% / 0.50 \%)$, in Turkey $(0.76 \% / 0.65 \%)$ (Stan rozvytku nauky i tekhniky, 2017).

Science in Ukraine is financed from various sources but the biggest cost loading is imposed to the state budget, further, the funds of enterprises, institutions

\begin{tabular}{|l|c|c|l|c|c|}
\hline Country & $\begin{array}{c}\text { Expenditures for } \\
\text { R\&D in \% from GDP }\end{array}$ & $\begin{array}{c}\text { Number of scientific } \\
\text { professionals per 1 } \\
\text { million of citizens }\end{array}$ & \multicolumn{1}{|c|}{ Country } & $\begin{array}{c}\text { Expenditures for } \\
\text { R\&D in \% from GDP }\end{array}$ & $\begin{array}{c}\text { Number of scientific } \\
\text { professionals per 1 } \\
\text { million of citizens }\end{array}$ \\
\hline Israel & 4,5 & 1900 & Qatar & 2,7 & 800 \\
\hline Japan & 4 & 6000 & France & 2,5 & 4000 \\
\hline Sweden & 3,7 & 5000 & Canada & 2 & 5000 \\
\hline Finland & 3,6 & 7500 & Great Britain & 2 & 4500 \\
\hline The USA & 3,5 & 7000 & Spain & 1,5 & 3500 \\
\hline Germany & 3 & 4500 & Ukraine & 0,7 & 1800 \\
\hline
\end{tabular}


and organizations, grants and financial resources of national and foreign customers and self-financing are used in various rations.

The situation in Ukraine turns out to be in a manner that either the private sector or other organizations are not interested in science support due to the fact that they do not receive support from the state. Today we can speak about paltry international support of science financing in Ukraine, for example, implementation of program "Horizon 2020" where Ukrainian scientific professionals cooperating actively with leading foreign universities and research institutes in various fields of sciences as a part of bilateral and European program; they arrange collaborative seminars and workshops (Forsayt ekonomiky Ukrayiny: (2015-2020).

As is seen from Fig. 3, 48\% of expenditures are accounted for by scientific and technological developments; ca. $25 \%$ are allocated to the performance of the fundamental researches; $18 \%$ are allocated to the performance of applied researches; $9 \%$ are allocated for the provision of scientific and technical services.

Financing of the fundamental researches contains $95 \%$ funds of state and local budgets; financing of applied researches contains $75 \%$ funds of state and local budget; $30 \%$ of scientific and technological developments financing are accounted for by the budget; $46 \%$ - by the funds of foreign companies and $24 \%$ - by the funds of national business sector.

Firstly, the material support of scientific research requiring considerable financial resources for the purposes of an upgrade of machinery and equipment remains a serious problem.

Secondly, the academic staff remains vulnerable. Level of the salary of scientists remains the key problem in this category. So, the occupational prestige decreases sharply. A number of scientists who emigrated abroad decreased over the last years. However, this problem continues to be extremely relevant by this day.
The analysis of outflow of academic staff points to the fact that it is those scientists who emigrate abroad who may offer new knowledge that has no future perspectives for development or application in our country. In addition, the multinational mobility of academic staff becomes rather a topical problem.

Many domestic scientists go to foreign scientific centres (for the purposes of on-the-job training or occasional employment) according to international treaties on cooperation. Displacement of centres of scientific and technological activity occurs in doing so. The fact that most of the scientists who stay in Ukraine deal with parallel kinds of activity (politics, entrepreneurship) also continues to be the topical issue.

Given this, the process of the efficient scientific activity decreases and sometimes becomes impossible. The national scientific potential does not fulfil the economic function under these circumstances, and it has long been emphasized by leading domestic scientists that the financial support problem may be solved according to the situation, that state support of science is such that the science may fulfil exclusively social and cultural function (Martynyuk, 2014).

Governmental grant for social and economic development of certain territories in the amount of 6.2 bln UAH was provided in the state budget in 2017. This grant was allocated between local budgets for the purposes of implementation of 10569 development project on the basis of Ordinances of the Cabinet of Ministers of Ukraine.

Out of the total number of R\&D deliverables (12425 units) produced in 2016 at the cost of common fund, $76.3 \%$ of R\&D deliverables was produced at the cost of 4 key spending units: Ministry of Education and Science (29.4\%), National Academy of Sciences (19.4\%), National Academy of Educational Sciences of Ukraine (17.3\%), the National Academy of Agrarian Sciences of Ukraine (10.2\%).

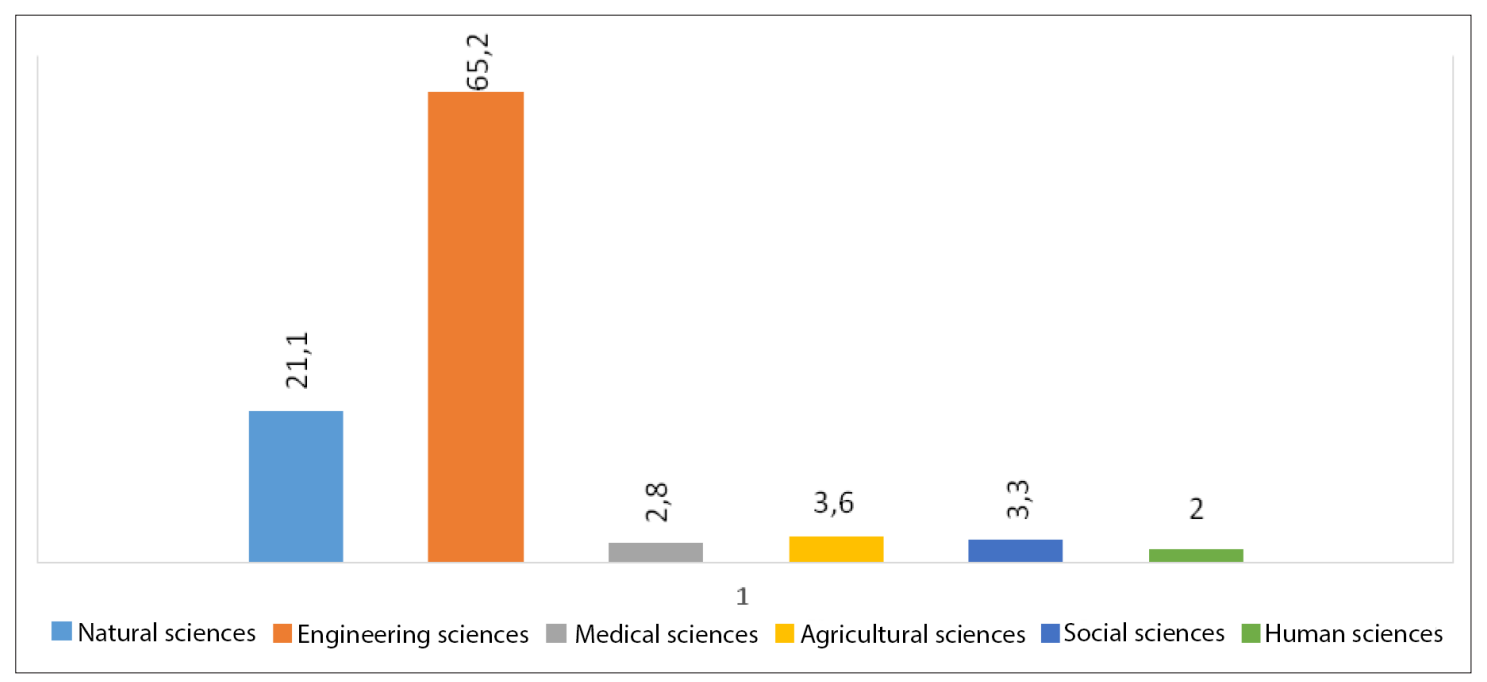

Fig. 3. Financing of developmental works according to fields of science (2016) (Stan rozvytku nauky i tekhniky, 2017) 
Vol. 4, No. 3, 2018

Baltic Journal of Economic Studies

Table 1

Analysis of produced R\&D deliverables according to results of developmental works in 2016

\begin{tabular}{|c|c|c|c|c|c|}
\hline \multirow{3}{*}{$\begin{array}{l}\text { Kind of R\&D } \\
\text { deliverables }\end{array}$} & \multirow{3}{*}{$\begin{array}{l}\text { Produced R\&D } \\
\text { deliverables, total } \\
\text { quantity of units }\end{array}$} & \multicolumn{4}{|c|}{ Including at the cost of } \\
\hline & & \multicolumn{2}{|c|}{ Common fund } & \multicolumn{2}{|c|}{ Special fund } \\
\hline & & Units & $\begin{array}{c}\text { Proportion from total } \\
\text { volume }(\%)\end{array}$ & Units & $\begin{array}{c}\text { Proportion from total } \\
\text { volume (\%) }\end{array}$ \\
\hline $\begin{array}{l}\text { Kinds of R\&D } \\
\text { deliverables }\end{array}$ & 910 & 417 & 45,8 & 493 & 54,2 \\
\hline Including machinery & 528 & 282 & 53,4 & 246 & 46,6 \\
\hline Technologies & 1337 & 880 & 65,8 & 457 & 34,2 \\
\hline Materials & 742 & 457 & 63,1 & 267 & 36,9 \\
\hline $\begin{array}{l}\text { Cultivars of plants } \\
\text { and breeds of animals }\end{array}$ & 226 & 22 & 98,2 & 4 & 1,8 \\
\hline Methods, theories & 5025 & 4124 & 82,1 & 901 & 17,9 \\
\hline Other & 9541 & 6325 & 66,3 & 3216 & 33,7 \\
\hline Total & 17663 & 12425 & 69,9 & 5338 & 30,1 \\
\hline
\end{tabular}

Source: made by the author on the basis of (Stan rozvytku nauky i tekhniky, 2017)

The quantity of implemented $\mathrm{R} \& \mathrm{D}$ deliverables is one of the most important indicators of the efficiency of use of budgetary funds allocated for R\&D financing. 63.5\% (7896 units of R\&D deliverables) was implemented from 12425 units of R\&D deliverables produced at the cost of common fund in 2016. The biggest proportion of produced R\&D deliverables $-62.0 \%$ (6797 units) is accounted for by the priority area "Fundamental scientific researches".

Level of R\&D deliverables implementation according to this priority area is equal to $55.2 \%$. R\&D deliverables produced according to priority area "Life sciences, new technologies of prevention and treatment of the most common diseases" have the highest level of implementation (92.4\%) (Stan rozvytku nauky i tekhniky, 2017).

Max Planck Society in Germany combining ca. 100 scientific establishments (some equivalent of the National Academy of Sciences of Ukraine) can become the experimentalmodel of regulation and financing of scientific, educational, and innovative activity of institutions. Society is sensitive to economic social challenges, so it changes the range of research trends, a number of institutions and establishments and amounts of financing dynamically according to demand and economic realities.

Researches conducted under the scope of the project have both fundamental and applied nature. The Max Planck Society is known by the developments of innovative materials and technologies. Fundamental principles of activity of institutes of the Max Planck Society are the following (Max Planck Innovation, 2018): - institutes may be legal entities;

- they are independent and autonomous in the arrangement of their researches;

- institutes have own budgets administered by the employees; - considerable budgetary financing is combined with grant financing and funds for commercial jobs;

- new topics are opened on the competitive basis with the involvement of external expertise;

-close cooperation betweeninstitutes andinterdisciplinary nature of researches is in common practice.
Such a system enables to use both short-term and long-term projects addressing needs of innovative development. A considerable attention is given to commercialization of scientific developments. The Innovation Centre "Max-Planck Innovation GmbH" was established under the Society. The Centre helps scientists to estimate the inventions, to patent them, to establish a start-up Company, to bring technologies to the market. The activity of the Max Planck Society is a successful example of cooperation between science and production, the transformation of key findings into products facilitating economic and social progress (Max Planck Innovation, 2018). Scientists from Max Planck Society are closely related to German universities, $80 \%$ of Dr. hab. are actively involved in the educational process. High level of the fundamental science enables to maintain a very high level of teaching at the leading universities. High priority is assigned to work with gifted youngsters, search for talented scientists. Establishment of 63 international research schools for $\mathrm{PhD}$ training in cooperation with the universities and worldwide scientific centres is the important factor of the Society activity. The system of research groups financing functions in research schools. Structures providing involvement of masters into the processes of the scientific cycle have the added advantage in scientific competition. Specified structures not only provide training of top-qualification staff in the field of science but also provide constant cooperation between international academic elite and talented youth (Shevchenko, Shadura, 2017). So, the efficient model of the Max Planck Society activity may become a certain example, according to which the reformed national scientific sphere will function.

Implementation of the new economic model in Ukraine is possible upon the condition of creation and adjustment of the functioning of two closed and related engineering processes: innovative and productive: education-science-production-market; investment. 


\section{Conclusions}

The structural analysis of regulation and financing of scientific, educational, and innovative activity of developed countries enabled to come to the following conclusions:

1. Scientific activity is carried out by state research establishments, higher educational institutions, as well as scientific units of privately owned enterprises, including big companies and corporations.

2. Governments of scientifically developed countries of the world carry out the regulation of scientific activity at the state level, using absolutely financial mechanisms for this purpose. State regulation of scientific activity is performed by direct (split-level budgetary financing, grants, subsidies, governmental grants, interest-free loans etc.) and indirect (preference schemes, tax discount, tax holidays etc.) financial support. Funds of private companies, non-profit organizations and foundations are used for the purpose of scientific activity financing. Such financing proportion increases constantly year by year.

3. Methods of work of institutions carrying out the scientific activity are based on constancy, independence, self-sufficiency, autonomy, openness, and high scientific standards. Global trends of scientific activity reformation are focused on the considerable extension of rights of scientific institutions in the allocation of budgetary financing, facilitation of administrative and bureaucratic procedures, expansion of independence of academic specialists, a decrease of a share of administrative expenses.

4. Creation of big research and production associations (technological, scientific parks, technopolis) is a common global trend of scientific-and-technological advance.

5. The system of assessment of the efficiency of state policy implementation in the field of science carried out for the purpose of determination of the level of performed works and provision of control over spent funds is the important element of scientific activity regulation.

Taking into account the current state of scientific activity financing, we developed the following proposals.

1. In order to achieve considerable positive changes in the organizational and economic direction, it is necessary: to improve the institutional fundamentals of state scientific and technological and innovative policy; to overcome the disunity and isolation among educational and scientific institutions; to form the national-level system of computer-assisted retrieval, collection, accumulation, analytical processing and storage, dissemination and provision of information in the field of scientific and technological and innovative development; to provide the creation of uniform technological and information infrastructure for science and innovative ventures in Ukraine; to create institutional fundamentals of market stimulation of innovative development; to improve the system of state financing of innovative processes, mechanisms of government orders in scientific and technological spheres, as well as the monitoring of the efficiency of the financing and implementation of scientific and innovative projects; to improve the efficiency of the functioning of special economic areas, to extend the network of innovative centres, technology parks, and other innovative structures.

2 . The necessity of provision of continuity of increase in the investments into researches in various years, in particular, crisis, needs the adjustment of state financing of researches towards its increase. Countries of the European Community established a goal come to the level of the financing of science averagely to the extents corresponding to 3\% GDP (and some of them exceed this indicator of R\&D/GDP intensity yet today) for the purpose of acceleration of innovative development of the economy by 2020. However, this indicator decreases more and more in Ukraine. Currently, it is equal to $0.2 \%$ GDP.

Summarizing all above-mentioned information, it should be pointed out that common concept of development of scientific and technological activity should be based on the provision of proper institutional transformations and use of series of economic incentives of all participants of scientific and technological activity.

The following may be classified as top priorities of development of scientific and technological activity in Ukraine: prevention of arrival of earlier and inefficient technologies; facilitation of application of state-ofthe-art highly efficient technologies, development of scientific potential and human resourcing; arrangement of conditions for extension and expansion in the number of innovative structures (technology parks, technopolis, business incubators, innovation centres, innovative exchange markets).

\section{References:}

Bolohib T.M. (2005). Finansuvannya nauky za kordonom [Financing science abroad]. Finansy Ukrayiny. № 4, pp. 46-53. (in Ukrainian)

Danylova I.P. (2014).Zarubizhnyy dosvid derzhavnoho rehulyuvannya naukovoyi sfery: teoretyko-metodolohichni rekomendatsiyi dlya Ukrayiny [Foreign experience of state regulation of the scientific sphere: theoretical and methodological recommendations for Ukraine]. Yuridicheskiy zhurnal: teoriya i praktika. Decembrie. Pp. 79-85.

Kuzhelyev M.O. (2015). Suchasnyy stan finansuvannya ukrayinskoyi nauky: problemy ta perspektyvy [Current state of financing of Ukrainian science: problems and perspectives]. Naukovyy visnyk Khersonskoho derzhavnoho universytetu. Vol. 13, № 3, pp. 129-131. (in Ukrainian)

Lutsenko T.A. (2015). Mizhnarodnyy dosvid derzhavnoho rehulyuvannya nauky ta innovatsiynoyi diyalnosti [International Experience in State Regulation of Science and Innovation]. Teoriya ta praktyka derzhavnoho upravlinnya. Vol. 2, pp. 311-316. Retrieved from: http://nbuv.gov.ua/UJRN/Tpdu_2015_2_50 (in Ukrainian) 
Martynyuk O.A. (2014). Suchasni mekhanizmy derzhavnoho rehulyuvannya innovatsiynoyi diyalnosti [Modern mechanisms of state regulation of innovation activity]. Naukovyy visnyk MHU. Seriya: Ekonomika ta menedzhment. No. 7, pp. 103-107. (in Ukrainian)

Panchenko A.I. (2011). Finansuvannya naukovoyi diyalnosti yak neobkhidna umova innovatsiynoho rozvytku derzhavy [Financing of scientific activity as a prerequisite for the innovative development of the state]. Stalyy rozvytok ekonomiky: Vseukrayinskyy naukovo-vyrobnychyy zhurnal. No. 7, pp. 45-50. (in Ukrainian)

Pro derzhavnyy byudzhet na 2018 rik: proekt Zakonu Ukrayiny (2018) [About the State Budget for 2018: Draft Law of Ukraine]. Retrieved from: http://www.minfin.gov.ua:8080/uploads/redactor/files/565c9e6b799bc.pdf (in Ukrainian)

Pysmennyy V.V., Pysmennyy V.I. (2013). Problemy finansuvannya nauky v Ukrayini ta sviti v umovakh formuvannya systemy ekonomiky znan [Problems of financing science in Ukraine and the world in the conditions of formation of a system of knowledge economy]. Visnyk Sumskoho natsionalnoho ahrarnoho universytetu. № 5, pp. 20-27. (in Ukrainian)

Pro vnutrishnye ta zovnishnye stanovyshche Ukrayiny v 2016 rotsi (2017). [On the Internal and External Situation of Ukraine in 2016]. Shchorichne Poslannya Prezydenta Ukrayiny do Verkhovnoyi Rady Ukrayiny. Kiev. (in Ukrainian)

Stan rozvytku nauky i tekhniky, rezultaty naukovoyi i naukovo-tekhnichnoyi diyalnosti za 2017 (2017). [Status of the development of science and technology, the results of scientific and scientific and technological activities in 2017]. Retrieved from: https://mon.gov.ua/storage/app/media/nauka/informatsiyno-analitychni/na-sajt-monad-kmu-11.07.17.pdf (in Ukrainian)

Forsayt ekonomiky Ukrayiny: serednostrokovyy (2015-2020) i dovhostrokovyy (2020-2030) chasovi horyzonty [Forecast of the Ukrainian economy: medium-term (2015-2020) and long-term (2020-2030) time horizons]. Retrieved from: http://wdc.org.ua/uk/sustainable-development/reports (in Ukrainian)

Shevchenko A., Shadura V. (2017). Doslidnytska «parasolka», abo reforma NANU [Research umbrella, or the reform of the National Academy of Sciences of Ukraine]. Retrieved from: http://gazeta.dt.ua/science/ doslidnicka-parasolka-abo-reforma-nanu- .html (in Ukrainian)

Yadranska O.V. (2007). Zarubizhnyy dosvid derzhavnoho rehulyuvannya nauky: osnovni formy ta napryamy [Foreign experience of state regulation of science: main forms and directions]. Zb. Naukovykh prats DonDUU. Seriya: Derzhavne upravlinnya. Vol. 93, № 8, pp. 63-68. (in Ukrainian)

Max Planck Innovation (2018). Retrieved from: http://www.max-planck-innovation.de/en 